\title{
THE SIMULATION ANALYSIS OF A PROPOSED ‘HYDRONIC RADIATOR' SYSTEM TOWARDS LOW COST HOUSING OPERATION IN TEMPERATE AND HOT TROPICAL CLIMATES
}

\author{
Masa Noguchi ${ }^{1}$ and Koon Beng Ooi ${ }^{2}$
}

\begin{abstract}
Fuel poverty is one of the global concerns affecting not only users' financial capacity or affordability for maintaining housing operation but also the occupants' health and wellbeing. Space heating and cooling require a relatively large amount of domestic energy use in housing. Therefore, this study was formed with the aim to propose an innovative approach to utilising free, clean renewable sources of energy applicable to the space heating and cooling of housing in both cold and hot regions. Accordingly, housing test facilities based in Melbourne, Australia, and Kuching, Malaysia, were selected and used for this study that examined the thermal performance of a proposed 'hydronic radiator' (HR) system through simulation and onsite measurements. The geothermal heat capacity of a 'vertical ground heat exchanger' (VGHE) installed in the house in Melbourne was examined previously by the authors and the VGHE measured data was also applied to this HR performance simulation. The water that circulates through the HRs is heated by sunlight and VGHE or cooled by night sky radiation. This study drew conclusions that the sole utilisation of renewable sources through these proposed HR space heating and cooling systems can provide thermally accessible or comfortable indoor living environments in both heating or cooling dominant regions. Thus, fuel poverty issues may be alleviated through HR system application. The HRs can remove a 'sensible' portion of metabolic heat, but they cannot effectively contribute to the 'latent' heat removal. Thus, the future potential use or effect of 'flow-through' HRs, which are integrated into a underfloor air distribution (UFAD) plenum, was also dsicussed in this study. In the test house located in Melbourne, the flow-through HR UFAD system is currently under development. Therefore, the performance will be measured once the system has come into operation for further testing.
\end{abstract}

\section{KEYWORDS}

Hydronic radiator, vertical ground heat exchanger, night sky radiation, solar thermal collector, photovoltaic power generating system, affordable low cost housing operation

1. ZEMCH Lab, Faculty of Architecture, Building and Planning, The University of Melbourne,Melbourne, Australia, masa.noguchi@ unimelb.edu.au

2. ZEMCH Lab, Faculty of Architecture, Building and Planning, The University of Melbourne, Melbourne, Australia, ooi_kb3@hotmail. com 


\section{INTRODUCTION}

In the 1970s, the notion of fuel poverty first emerged in the United Kingdom following the global oil crisis (Benvenuti 2012). The issue became conspicuous globally due to the hike of energy prices. The cause derives from various circumstances including poor quality housing, affecting particularly vulnerable families' health and wellbeing. Space heating and cooling requires a relatively large amount of energy consumption in housing operation that is greatly contributing to acceleration of the fuel poverty problem. The ground contains constant heat which can be considered as a stable renewable source of energy, and it can raise water temperature to $50^{\circ} \mathrm{C}$ or even more. Using an Emerson ${ }^{\text {TM }}$ recorder, the authors of this paper previously recorded a $2^{\circ} \mathrm{C}$ increase in the ground temperature at $50 \mathrm{~m}$ in depth from the ground level of a house located in Melbourne, Australia (Ooi and Noguchi 2017). Furthermore, during the daytime, free clean solar energy is generally available for the buildings' space and water heating (as well as lighting). During the night-time, low atmospheric temperature outside the house can contribute to cooling space and water effectively when they are exposed to the sky. Thus, the proper use of these renewable sources may help reduce or eliminate the operational energy costs of housing and this may, in turn, provide resilience for the alleviation of fuel poverty problems. Accordingly, this study was formed with the aim to explore the optimal sole use of these free, clean renewable sources by implementing hydronic radiators (HRs) proposed for space heating and cooling of houses in temperate and hot tropical climates. To examine the space heating response in a temperate climate, this study utilised a housing test facility located in Melbourne, Australia, while one in Kuching, Malaysia, was applied to further space cooling simulations under hot tropical conditions. The following sections will identify research methods and outcomes.

\section{METHODS}

In this study, "EnergyPlus" was used for hydronic radiator (HR) performance simulations under both cool and hot climatic conditions (National Renewable Energy Laboratory 2018). The HR system proposed in this study was designed to extract heat from the ground and/or sunlight for space heating of an experimental house in Melbourne, Australia. In addition to the geothermal and solar energy application to the space heating, this HR performance simulation study also explored the effect of circulated water exposed to nigh-time sky radiation on space cooling of housing in Kuching, Malaysia. These simulations were modelled based on the EnergyPlus' "Low TemperatureRadiant:VariableFlow" object validated by Chantrasrisalai et al. (2003) (Table 1). It tested 3 simulation scenarios (or cases) to examine the HR performances using partially onsite monitoring data of the solar and geothermal equipment installed in the housing facilities built in Melbourne and Kuching.

\subsection{HR Space Heating Performance Analysis Context in Melbourne, Australia}

The long- and short-time borehole temperature responses (i.e. g-functions) were examined by Eskilson (1987) and Yavusturk and Spitler (1999). This simulation applied the g-functions to the EnergyPlus ${ }^{\mathrm{TM}} 35$ pairs of non-dimensionalised times to model vertical ground heat exchanger (VGHE) effects. An experimental housing facility was constructed in the south-east area of Melbourne, equipped with a 50m deep VGHE (Figure 1). This test house is elongated having a south-west facing front entrance. The house's layout and orientation are shown in Figure 1 (Left) that also indicates the location of the $50 \mathrm{~m}$ deep VGHE. It is located on the north-east side of the $3 \mathrm{~m}$ (width) $\times 6 \mathrm{~m}$ (length) living and bedroom area. The dwelling unit is covered 
TABLE 1. LowTemperatureRadiant:VariableFlow object modelled for heating.

\begin{tabular}{|c|c|c|}
\hline Name of Field & Entry & Notes \\
\hline Name & Living Wall Radiator & - \\
\hline Availability Schedule Name & ColdMthsAvailSchedule & - \\
\hline Zone Name & LivingSpace & Living Area \\
\hline $\begin{array}{l}\text { Surface Name or Radiant Surface } \\
\text { Group Name }\end{array}$ & LivingRadWalls & LTRs on opposite long walls \\
\hline $\begin{array}{l}\text { Hydronic Tubing Inside } \\
\text { Diameter }(\mathrm{m})\end{array}$ & 0.013 & - \\
\hline Hydronic Tubing Length (m) & autosize & - \\
\hline aTemperature Control Type & OperativeTemperature & \multirow{10}{*}{$\begin{array}{l}\text { These fields are used for } \\
\text { simulation run for the cold } \\
\text { portion of the year ( } 22 \text { March } \\
\text { to } 21 \text { November). Separate } \\
\text { fields (not shown) are used for } \\
\text { simulation run for the cold } \\
\text { portion ( } 22 \text { November to } 21 \\
\text { March) of the year. }\end{array}$} \\
\hline $\begin{array}{l}\text { Heating Design Capacity } \\
\text { Method }\end{array}$ & HeatingDesignCapacity & \\
\hline Heating Design Capacity (W) & autosize & \\
\hline $\begin{array}{l}\text { Heating Design Capacity Per } \\
\text { Floor Area }\left(\mathrm{W} / \mathrm{m}^{2}\right)\end{array}$ & - & \\
\hline $\begin{array}{l}\text { Fraction Autosized Heating } \\
\text { Design Capacity }\end{array}$ & 1 & \\
\hline $\begin{array}{l}\text { Maximum Hot Water Flow } \\
\left(\mathrm{m}^{3} / \mathrm{s}\right)\end{array}$ & autosize & \\
\hline Heating Water Inlet Node Name & Living Wall Pump Outlet Node & \\
\hline $\begin{array}{l}\text { Heating Water Outlet Node } \\
\text { Name }\end{array}$ & $\begin{array}{l}\text { Living Wall Radiator GW Outlet } \\
\text { Node }\end{array}$ & \\
\hline $\begin{array}{l}\text { Heating Control Throttling } \\
\text { Range }\left({ }^{\circ} \mathrm{C}\right)\end{array}$ & 0.5 & \\
\hline $\begin{array}{l}\text { Heating Control Temperature } \\
\text { Schedule Name }\end{array}$ & Heating SetPoint (living) & \\
\hline $\begin{array}{l}\text { Condensation Control Type } \\
\text { Condensation Control Dewpoint } \\
\text { Offset }\left({ }^{\circ} \mathrm{C}\right)\end{array}$ & - & $\begin{array}{l}\text { Used with entries in 'Cooling } \\
\text { fields }\end{array}$ \\
\hline Number of Circuits & CalculateFromCircuitLength & - \\
\hline Circuit Length & 200 & - \\
\hline
\end{tabular}

with recycled metallic-clad structural insulated panels (SIPs). Figure 1 (Right) shows the white surface SIPs and an insulated metallic $4.88 \mathrm{~m}$ (width) $\times 6 \mathrm{~m}$ (length) garage attached to the north-west side of the $18 \mathrm{~m}^{2}$ living and bedroom area. The thickness of SIPs applied to the floor, wall and ceiling/roof is $100 \mathrm{~mm}, 150 \mathrm{~mm}$ and $200 \mathrm{~mm}$, respectively. This double garage is now equipped with $50 \mathrm{~mm}$ and $75 \mathrm{~mm}$ thick insulation batts in the wall and roof, respectively, and only half of the garage area is actually used as a car parking space today. 
FIGURE 1. An experimental house built in Melbourne: Layout (Left) and external appearance (Right).
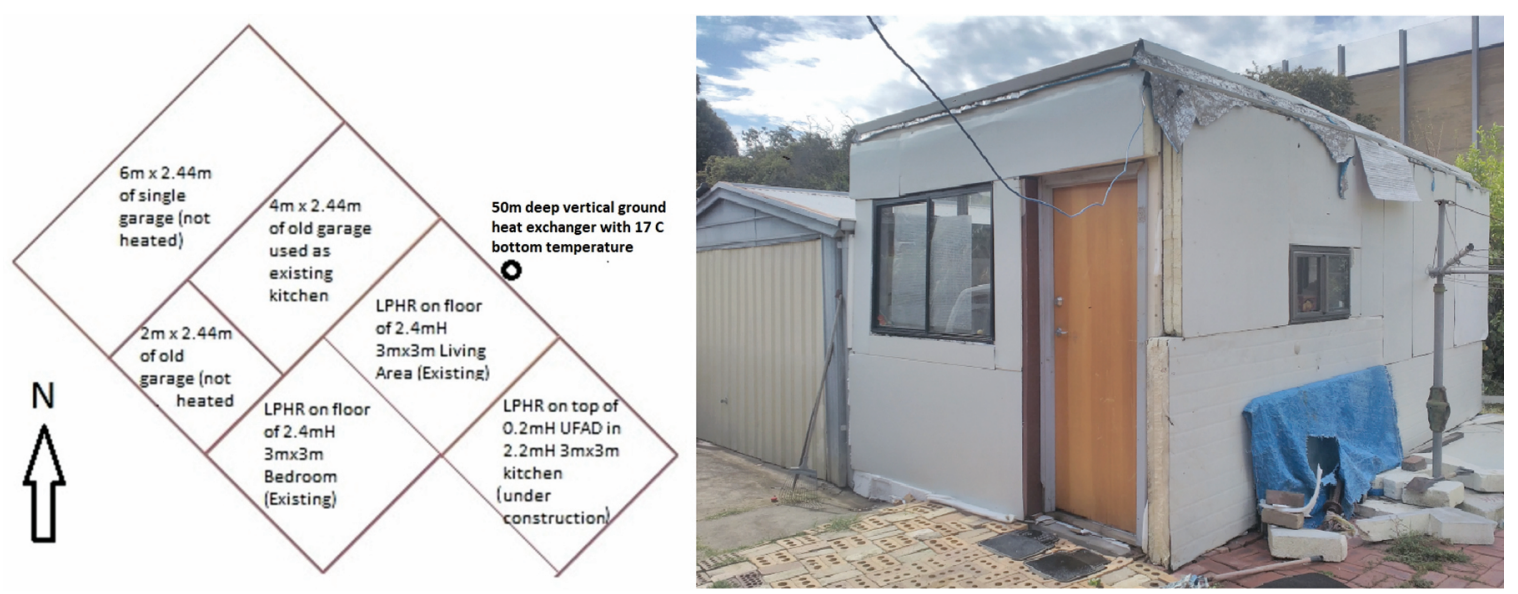

In the Melbourne experimental house, an R-value of $200 \mathrm{~mm}$ thick insulation applied to the ceiling/roof was estimated at $5 \mathrm{~m}^{2} \mathrm{~K} / \mathrm{W}$ (Fig. 3). Above the plasterboard and insulation batts (or metallic-clad polystyrene in the middle), there are a reflective foil, air gap and a metallic roof having a $30 \mathrm{~mm}$ high ridge that provides ventilation, which is desirable particularly during the summer. Two $0.4 \mathrm{~m}$ (height) and $3 \mathrm{~m}$ (width) double glazed windows are installed in the north-west walls of the open floor living and bedroom area (Figure 3). The window area is more than $12 \%$ of the floor area and the ratio led to a concern that ". . . problems with glare or fading of fabrics are likely to occur, and it becomes more difficult to provide enough thermal mass for year-round comfort" (Zeiler and Boxem 2008). Therefore, a 100W solar photovoltaic (PV) shading panel was placed in one of the windows so that the PV shading helps reduce or eliminate the undesirable glare or weathering (Figure 3). The dark colour panel absorbs solar radiation while the PV generates electricity and heat. The PV heat generation, in turn, warms up air between the window panes and beyond. These windows are mostly closed during the winter; thus, the PV panel stays in a vertical position. Conversely, during the summer, these windows remain mostly open for natural ventilation and the tilted PV receives sunlight in a

\section{FIGURE 2}

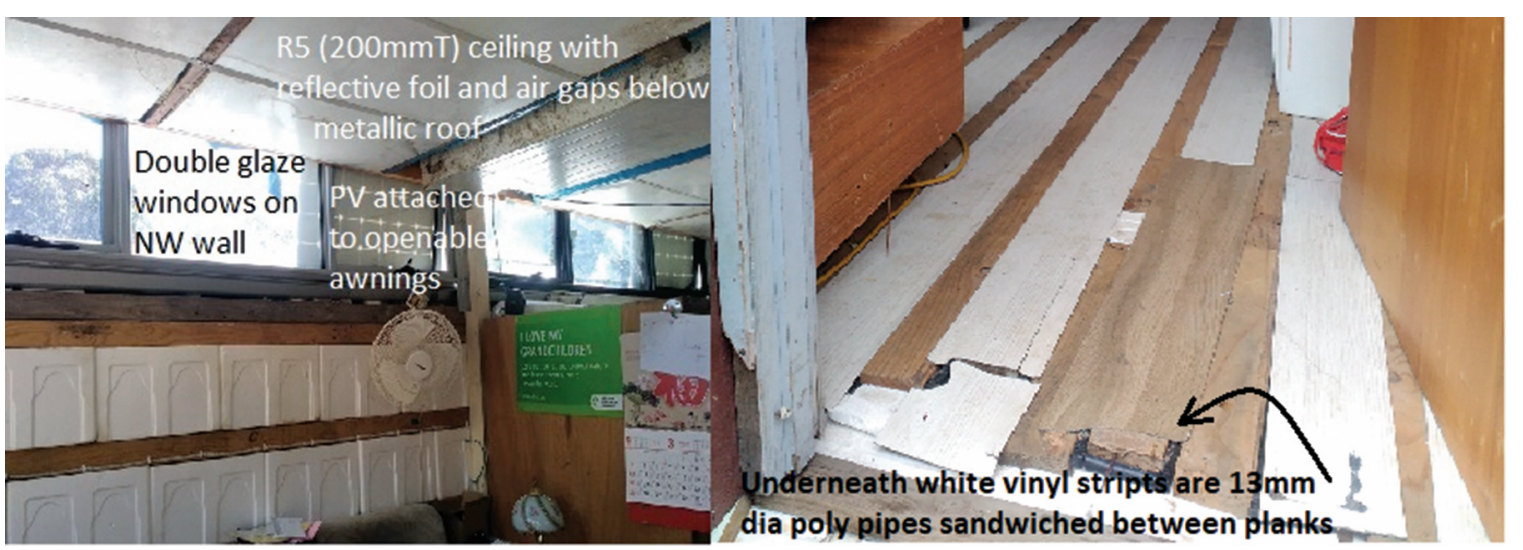


FIGURE 3. Double glazed windows with a PV panel on the north-west wall (Left) and the floor-HR with $13 \mathrm{~mm}$ poly pipes (Right).

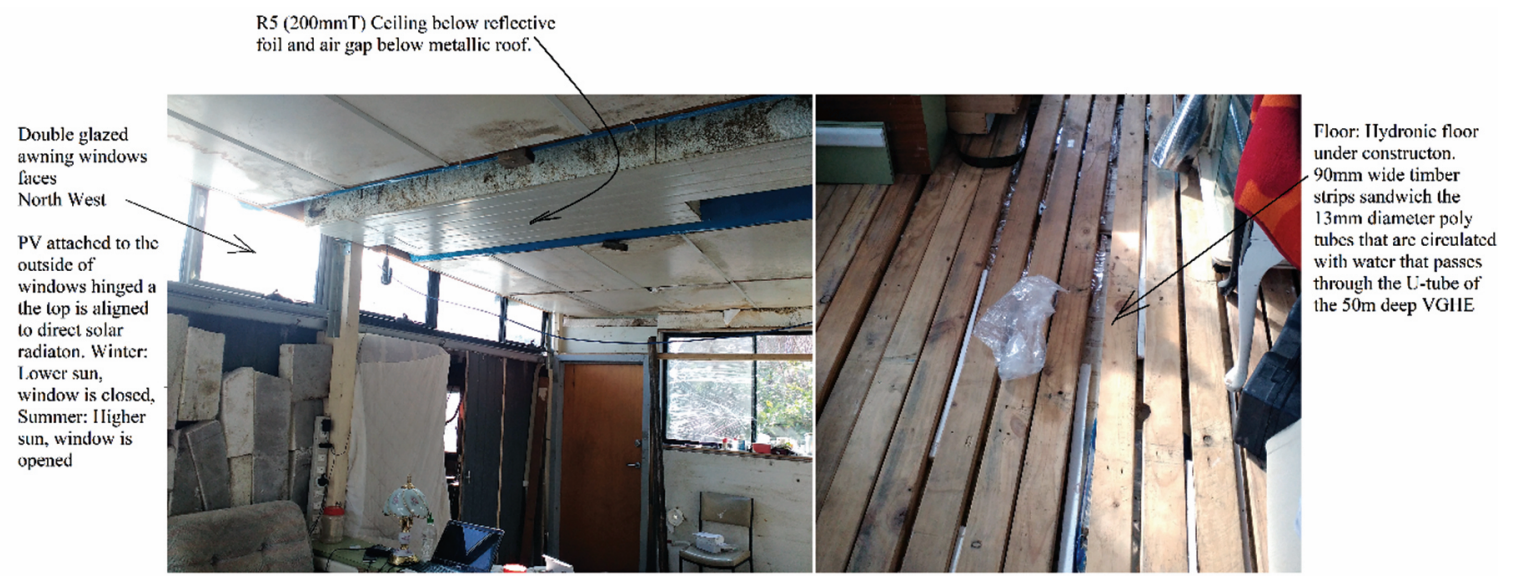

way that generates more electricity than in the winter-nonetheless, the PV heated air can be well ventilated.

Figure 3 (Right) shows the configuration of a floor hydronic radiator (floor-HR) installed in the house where $13 \mathrm{~mm}$ poly pipes are inlayed between $90 \mathrm{~mm}$ (width) wood planks. The schematic diagram can also be found in Figures 4 and 5. The black poly pipes are covered with vinyl strips. Below the floor-HR, $100 \mathrm{~mm}$ thick metallic-clad SIP is put in place. The overall performance of HRs installed in the house were examined under the conditions in which the water that circulates through HRs was extracted from either a 50m deep VGHE or $1.2 \mathrm{~m}^{3}$ tank connected to a solar flat plate collector located on the north-west facing roof of the garage.

FIGURE 4. HR wall and floor sections.

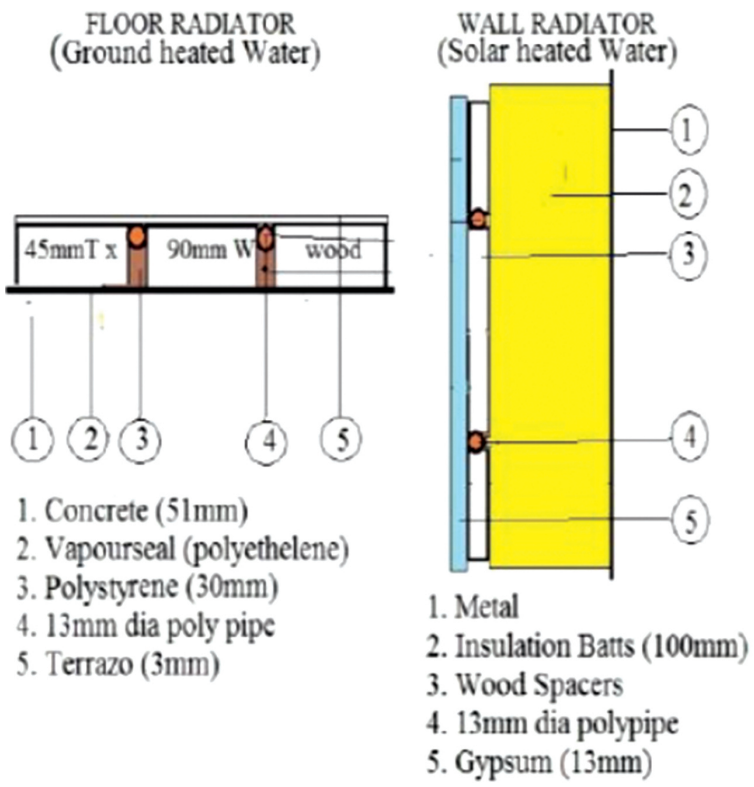


FIGURE 5. Common pipe for the VGHE supply loop and low temperature radiator branch loop.

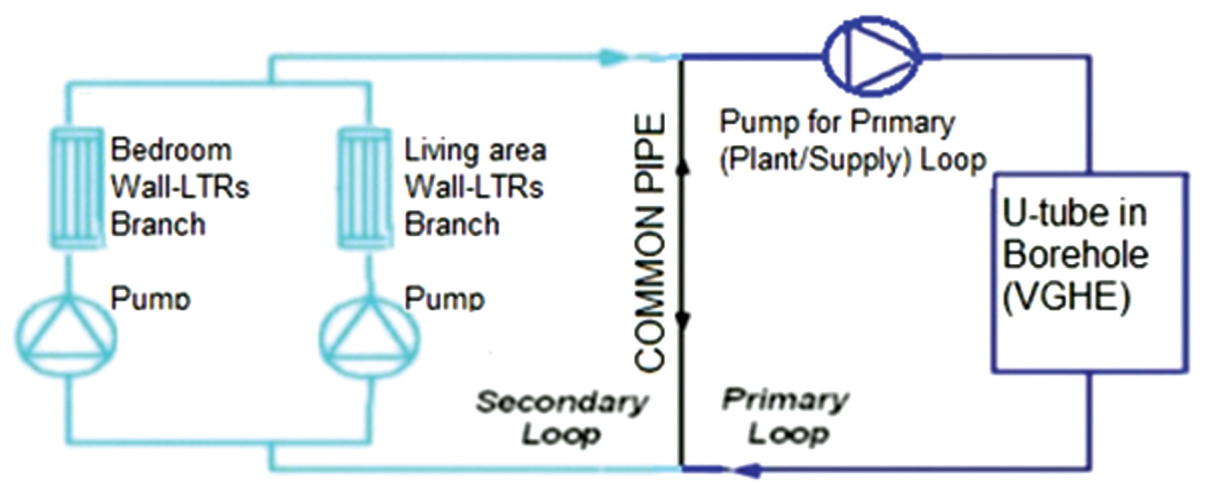

\subsection{HR Space Cooling Performance Analysis Context in Kuching, Malaysia}

The simulation study for HR space cooling effects was condcuted using a similar test house senario as described above; however, Kuching, Malysia, was applied to the climatic condition. Nonetheless, the cooled water circulates through HRs. Figure 6 (left) illustrates a water tank located in Kuching having tubes tilted exposed to the night sky. The round $400 \mathrm{~mm}$ diameter drum that stores water is placed in a $1.2 \mathrm{~m}^{2}$ wooden casket, where polystyrene insulation boards are inserted into the void between them. Even in the hottest month (i.e. June) in Kuching, the tempeature of water stored in the $200 \mathrm{~L}$ drum can be reduced to less than $25^{\circ} \mathrm{C}$ at sunrise. The water stored is cooled by radiation to the night sky. During the afternoon test, this night cooled water is circulated through the $\mathrm{HR}$ placed on the wall. The temperature of the return water to the top of the $1 \mathrm{~m}$ tall drum rises to above $26^{\circ} \mathrm{C}$. The water temperature remains at $25^{\circ} \mathrm{C}$ when measured at the bottom. Nonetheless, condensation occurred on the HR hydronic tube surfaces.

Figure 6 (Right) shows black poly pipes ( $45 \mathrm{~m}$ in total length and $0.013 \mathrm{~m}$ in diameter) are formed into eight coils that are affixed to a metallic-clad polystyrene board $(0.8 \mathrm{~m}$ high and $0.05 \mathrm{~m}$ thick) appearing in the external wall under the window.

Table 2 summarises the research features of this HR performance simulation that partially incorporated the authors' onsite measurement data. Table 3 further identifies the instruments used for the onsite measurements and explains their characteristics and accuracy.

FIGURE 6. Radiation to night sky and thermal storage (Left) and HR on bottom wall in Kuching (Right).

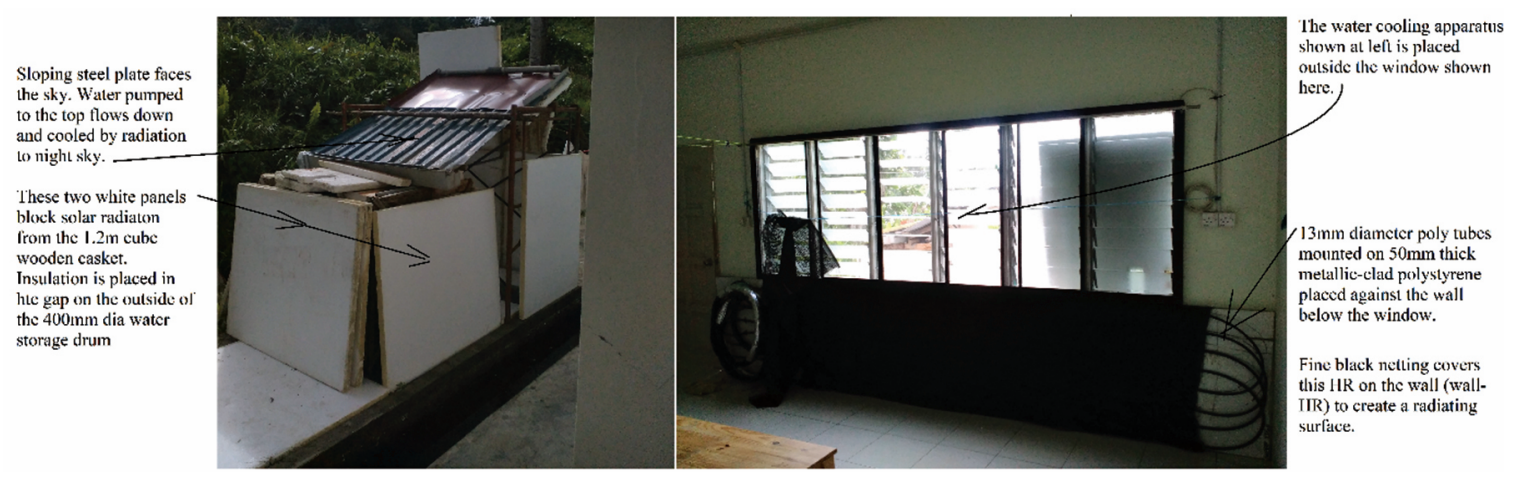


TABLE 2. Proposed HR space heating or cooling system overviews.

\begin{tabular}{|c|c|c|c|}
\hline $\begin{array}{l}\text { Location } \\
\text { (Latitude, Longitude) }\end{array}$ & \multicolumn{2}{|c|}{$\begin{array}{l}\text { Melbourne, Australia } \\
\left(-31.82^{\circ} \mathrm{N}, 144.97^{\circ} \mathrm{E}\right)\end{array}$} & $\begin{array}{l}\text { Kuching, Malaysia } \\
\left(1.52^{\circ} \mathrm{N}, 110.35^{\circ} \mathrm{E}\right)\end{array}$ \\
\hline Climate condition & Cold (Winter) & Hot (Summer) & Hot tropical \\
\hline Space heating or cooling need & Heating & \multicolumn{2}{|l|}{ Cooling } \\
\hline Primary method & $\mathrm{HR}^{1}$ & \multicolumn{2}{|l|}{ Air movement from fan ${ }^{2}$} \\
\hline $\begin{array}{l}\text { Alternative or secondary cooling } \\
\text { system }\end{array}$ & - & $\begin{array}{l}\text { Alternative cooling: } \\
\text { Evaporative cooler }\end{array}$ & $\begin{array}{l}\text { Secondary cooling: } \\
\mathrm{HR}^{1}\end{array}$ \\
\hline Cooling or heating source & $\mathrm{VGHE}^{4}$ & - & Night cooling 5 \\
\hline Heat replenished by & - & Solar-heated water ${ }^{6}$ & - \\
\hline $\begin{array}{l}\text { Booster source (when VGHE is } \\
\text { insufficiently hot or night-cool } \\
\text { water insufficiently cold) }\end{array}$ & \multicolumn{2}{|c|}{$\begin{array}{l}\text { Indoor tank with water heated by solar } \\
\text { collectors to } 50^{\circ} \mathrm{C} \text { by end of summer }\end{array}$} & $\begin{array}{l}\text { Chiller run by } \\
\text { photovoltaic }{ }^{8} \text { for hot } \\
\text { sunny days }\end{array}$ \\
\hline $\begin{array}{l}\text { Ventilation to remove latent } \\
\text { portion of metabolic heat }\end{array}$ & \multicolumn{2}{|c|}{$\begin{array}{l}\text { Outdoor air enters via windows in the } \\
\text { living area, grilles in the UFAD wall and } \\
\text { upwards via gaps in 'flow-through' HR }\end{array}$} & $\begin{array}{l}\text { Air movement from } \\
\text { fans and openable } \\
\text { windows }\end{array}$ \\
\hline Onsite power from & \multicolumn{3}{|c|}{ Rooftop photovoltaic and battery } \\
\hline
\end{tabular}

${ }^{1}$ Low temperature 'Hydronic Radiator' (HR) is installed in the internal surface of building envelope through which water heated at $16-26^{\circ} \mathrm{C}$ can circulates. Floor-HR constructed in the experiment house was tested with water drawn from the 50m deep 'Vertical Ground Heat Exchanger' (VGHE) and water heated by solar thermal collectors can be stored in an indoor tank. For space cooling in humid tropical climates, night-time sky cooled water is applied to wall-HRs.

${ }^{2} \mathrm{Air}$ movement of approximately $1 \mathrm{~m} / \mathrm{s}$ tends to create a cooling sensation of up to $4^{\circ} \mathrm{C}$. It is achievable from ceiling or stand fans, which can also be used for ventilation in the summer. In tropical countries, thermallycomfortable-with-fan temperature is up to $30.5^{\circ} \mathrm{C}$

${ }^{3}$ Evaporative cooling is used in many existing houses in seasonal climates which have lower humidity like Melbourne, Australia.

${ }^{4}$ Water drawn from $50 \mathrm{~m}$ and $100 \mathrm{~m}$ deep VGHE in south eastern Melbourne has been measured on site at $15-17^{\circ} \mathrm{C}$ and $22-24^{\circ} \mathrm{C}$, respectively. These depths are about half of those calculated for Melbourne's annual average temperature of $15^{\circ} \mathrm{C}$ using IPCC 2008 data of $25-30^{\circ} \mathrm{C} / \mathrm{km}$ depth. For places with annual average temperature of $0^{\circ} \mathrm{C}$, the VGHE depth would be between 1 to $2 \mathrm{~km}$.

${ }^{5}$ Typical Meteorological Year (TMY) weather data for Kuching, Malaysia, shows night sky temperature is not more than $25^{\circ} \mathrm{C}$. This is measured in water cooled by radiation to the night sky in June/July of 2015 to 2017.

${ }^{6}$ Simulations show that during the summer in Melbourne, 30 evacuated tubes could collect 1.2 MWh of heat. This solar-heated water can replace the heat extracted from VGHE for $144 \mathrm{~m}^{2}$ family-sized houses.

$750 \mathrm{~m}$ deep VGHE in Melbourne has the capacity for heating water to $15-17^{\circ} \mathrm{C}$ only. Thus, it is used in floor-HR and solar thermal collectors are used to heat water for wall-HRs. A $2 \mathrm{~m}^{3}$ indoor tank is used as a buffer storage for less solar radiation in the winter. At the end of winter, the water stored in the tank was still approximately $25^{\circ} \mathrm{C}$ when measured on site.

${ }^{8}$ June/July 2017 summer experiments in Kuching show that it was difficult to maintain the night-cooled water at $25^{\circ} \mathrm{C}$ until the afternoon when cool water is desirable. Cooling coils of a solar-powered chiller is applicable to boosting coldness of the water in the summer. This extra coldness can be expected to match the need to alleviate the indoor heat as hot days are usually sunny. 
TABLE 3. Instruments and accuracy for onsite measurement.

\begin{tabular}{|l|l|l|}
\hline Make & Model & Accuracy \\
\hline Fluid in glass tube thermometer & Range 0 to $50^{\circ} \mathrm{C}$ & $\begin{array}{l}\text { By eye of about } 0.5^{\circ} \mathrm{C} \\
2 \mathrm{~mm} \text { division per }{ }^{\circ} \mathrm{C}\end{array}$ \\
\hline $\begin{array}{l}\text { Elitech RC-4HC } \\
\text { (future experiment) }\end{array}$ & $\begin{array}{l}\text { Temperature measuring range: } \\
30^{\circ} \mathrm{C} \sim+60^{\circ} \mathrm{C} \\
\text { external sensor } \\
(\text { cable length } 1.1 \mathrm{~m}) \\
-40^{\circ} \mathrm{C} \sim+85^{\circ} \mathrm{C} \\
\text { Humidity measuring range: } \\
0 \sim 99 \% \mathrm{RH}\end{array}$ & $\begin{array}{l}\text { Temperature accuracy: } \\
\pm 0.5^{\circ} \mathrm{C} / 0.9^{\circ} \mathrm{F} \\
\left(-20^{\circ} \mathrm{C} \sim 40^{\circ} \mathrm{C}\right) \\
\text { Humidity accuracy: } \\
\text { Approximately } 3 \% \mathrm{RH} \\
\left(25^{\circ} \mathrm{C}, 20 \sim 90 \% \mathrm{RH}\right)\end{array}$ \\
\hline $\begin{array}{l}\text { TPI Digital Thermometer } \\
343 \text { with Type } \mathrm{K} \text { thermocouple }\end{array}$ & $\begin{array}{l}+/-0.56^{\circ} \mathrm{C} \text { system }(\mathrm{tester} \& \\
\text { probe }) \text { accuracy within }-1^{\circ} \mathrm{C} \text { to } \\
48.88^{\circ} \mathrm{C} \text { temperature range }\end{array}$ \\
\hline $\begin{array}{l}\text { Fluke 62 Mini Infrared } \\
\text { thermometer (monitoring) }\end{array}$ & Fluke 62 IR Thermometer & \\
\hline
\end{tabular}

\section{RESULTS}

This study simulated the space heating and cooling capacity of a proposed hydronic radiator (HR) system using housing facilities based in Melbourne (temperate climate), Australia, and Kuching (hot tropical climate), Malaysia. The following sections summarise the results of 3 simulation cases within the two climate zones set in this research.

\subsection{HR Space Heating Results of $15-17^{\circ} \mathrm{C}$ VGHE Water to the Floor and Solar Heated Water to the Wall}

Figure 7 illustrates the simulation results of the test house's daily activity area on the coldest week in Melbourne. The indoor space studied includes a living and bedroom area and one third of the existing garage being used as a temporary kitchen. Water circulates through the floor-HR, heated to the bottom temperature of $17^{\circ} \mathrm{C}$ drawn from VGHE. Other water heated by a $2 \mathrm{~mm}$ thick $\times 750 \mathrm{~mm}$ wide $\times 6 \mathrm{~m}$ long glazed solar flat plate collector runs through the wall-HR connected to a $2 \mathrm{~m}^{3}$ indoor tank storage. The combined results indicate that the indoor temperature of the living room can reach approximately $20^{\circ} \mathrm{C}$ during the hours that occupants are normally active (i.e. from 8 am to midnight in this study) although the outdoor temperature is less than $15^{\circ} \mathrm{C}$. A thermostat in the bedroom controls HR operations. The daytime thermostat is set to be $18^{\circ} \mathrm{C}$ from 7 am to 9 am and from $4 \mathrm{pm}$ to the midnight, while the night-time is constantly at $15^{\circ} \mathrm{C}$. Around noon of the 1 st and 6th of July, the indoor temperature rose to approximately $24^{\circ} \mathrm{C}$ due to the level of solar radiation that penetrates the $400 \mathrm{~mm}$ high north-west facing double-glazed windows. Heating rates (in Watt) are also shown on the secondary vertical axis in Figure 5. The spikes in the heating rates at $7 \mathrm{am}$ reflect a series of setbacks caused in relation to thermostat operations. 
FIGURE 7. Temperature and heating rate of the living and bedroom area on the coldest week in Melbourne.

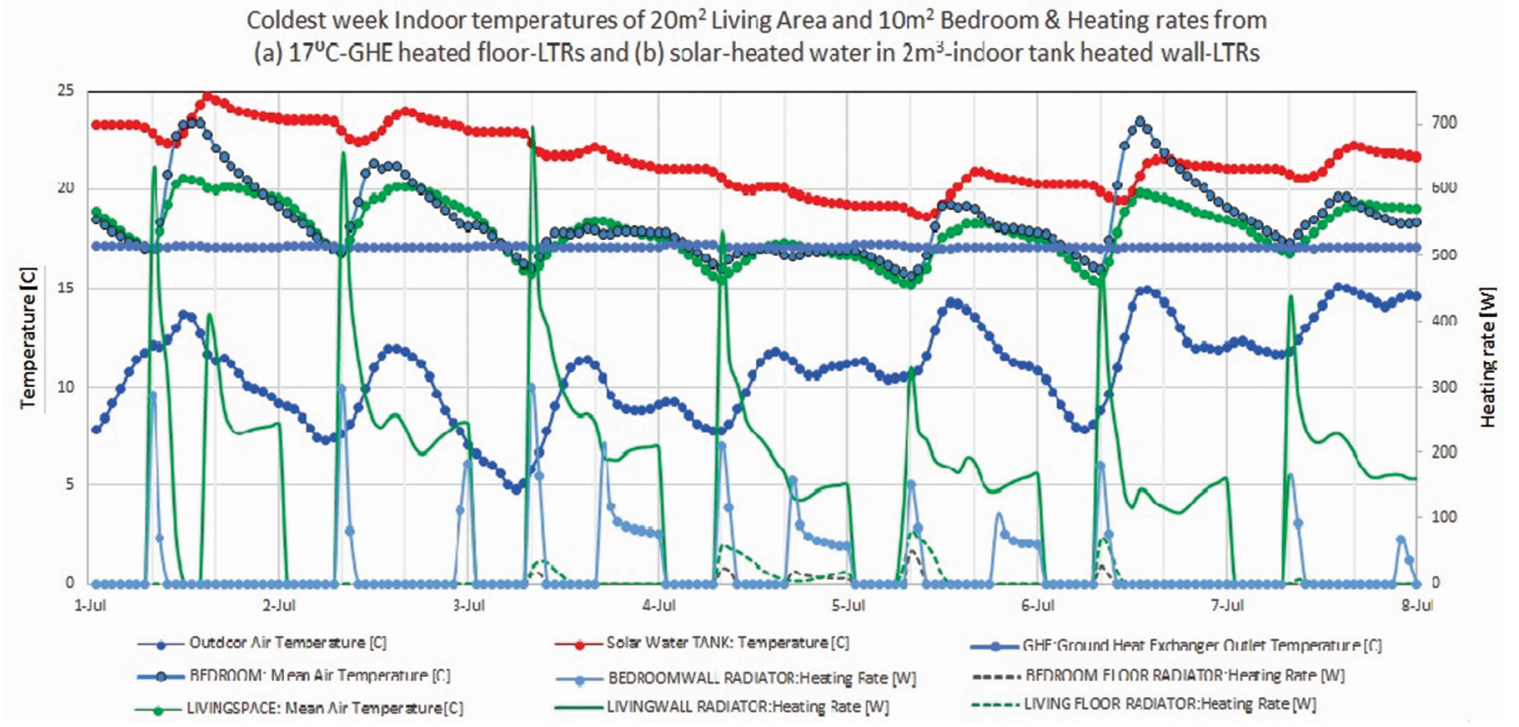

\subsection{HR Space Heating Results of VGHE Surrounded by the Ground with Average $23^{\circ} \mathrm{C}$ Temperature}

The HR performance using a vertical ground heat exchanger (VGHE) surrounded by the ground with the average temperature of $23^{\circ} \mathrm{C}$ was also simulated under the same housing and climatic conditions in Melbourne. In the test house, water running through the VGHE U-tubes is further applied to the HR placed inside the $6 \mathrm{~m}$ long walls. The results assure that the indoor temperature of the living and bedroom area remain within a range from $15^{\circ} \mathrm{C}$ to $20^{\circ} \mathrm{C}$ during the hours that occupants are usually active (Figure 8).

FIGURE 8. Temperature and heating rate of the living and bedroom area on the coldest week in Melbourne.

Coldest week temperatures of $20 \mathrm{~m}^{2}$ Living Area and $10 \mathrm{~m}^{2}$ Bedroom with $0.4 \mathrm{mH}$ double-glazed North windows \& Heating rates from LTRs on $6 \mathrm{~mL}$ East and West walls circulated with water from $23^{\circ} \mathrm{C}$ bottom-temperature $\mathrm{GHE}$

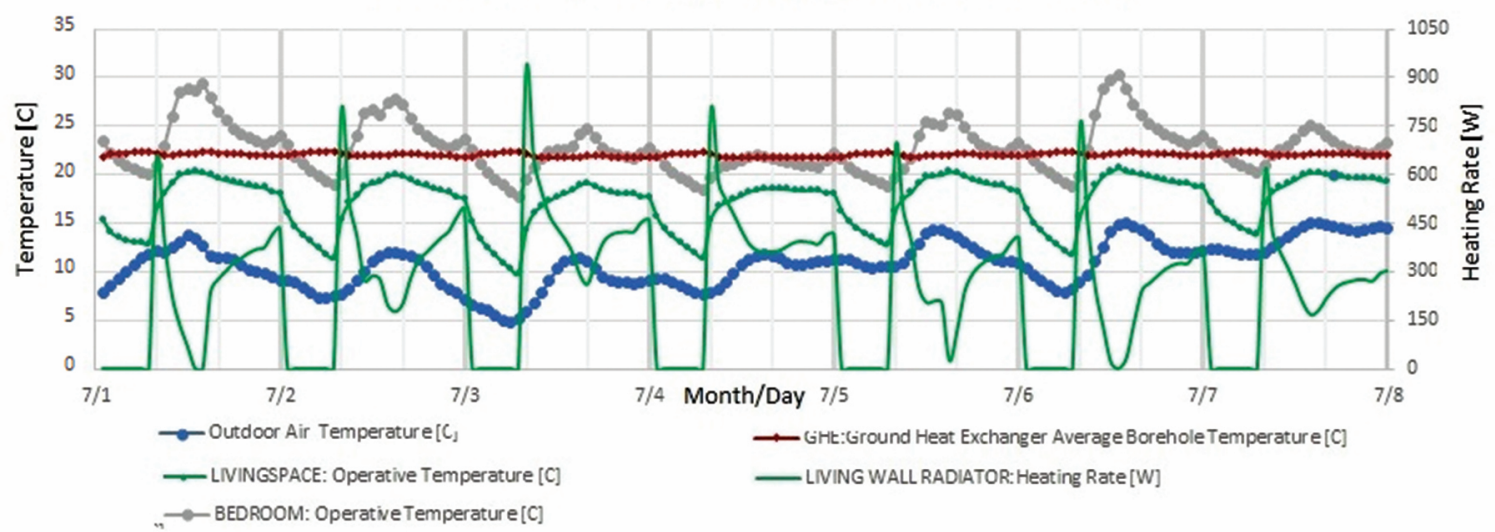




\subsection{HR Space Cooling Results of Night-Time Sky Radiation}

This study was extended to the analysis of HR performance for space cooling of housing in a hot tropical region. A house like one tested in Melbourne was assumed for the modelling of this HR space cooling simulation and geographically, Kuching, Malaysia, which has an existing test facility that the authors of this paper can access, was selected for the climatic setting. When the outdoor temperature in Kuching exceeds the local average at $0.4 \%$ of the year, the $25^{\circ} \mathrm{C}$ night-cooled water stored in a $0.3 \mathrm{~m}^{3}$ insulated tank circulates through the wall-HRs of a single-storey row house. According to the simulation, the indoor temperature could be reduced to $30.5^{\circ} \mathrm{C}$ (Figure 9). This temperature is close to the level that can be achieved through the operation of ceiling or stand fans.

\section{DISCUSSION}

The proposed hydronic radiator (HR) system is applicable to housing in cold and hot regions, yet according to the climatic conditions, renewable sources used for heating or cooling water that circulates through HRs need to be adjusted. In addition to the analysis of simulation results, the HR system's future upgrade to accommodate a ventilation capacity to remove occupants' latent heat that can be accumulated in a dwelling's indoor environment, will also be discussed.

Thermal comfort achieved by the HR space heating system in a temperate climate: The simulation results indicate that when the temperature of internal surfaces (i.e. walls and floors) of building envelopes is retained at $16-23^{\circ} \mathrm{C}$, the indoor environment of a house in Melbourne, Australia, can be thermally acceptable or comfortable. A $50 \mathrm{~m}$ deep 'vertical ground heat exchanger' (VGHE) can warm up water that circulates through the VGHE to $16^{\circ} \mathrm{C}$ and this heat can be further applied to floor-HRs that come into operation throughout both daytime

FIGURE 9. Simulated temperatures for thermally stored $25^{\circ} \mathrm{C}$ water in HR of hottest west-end unit.

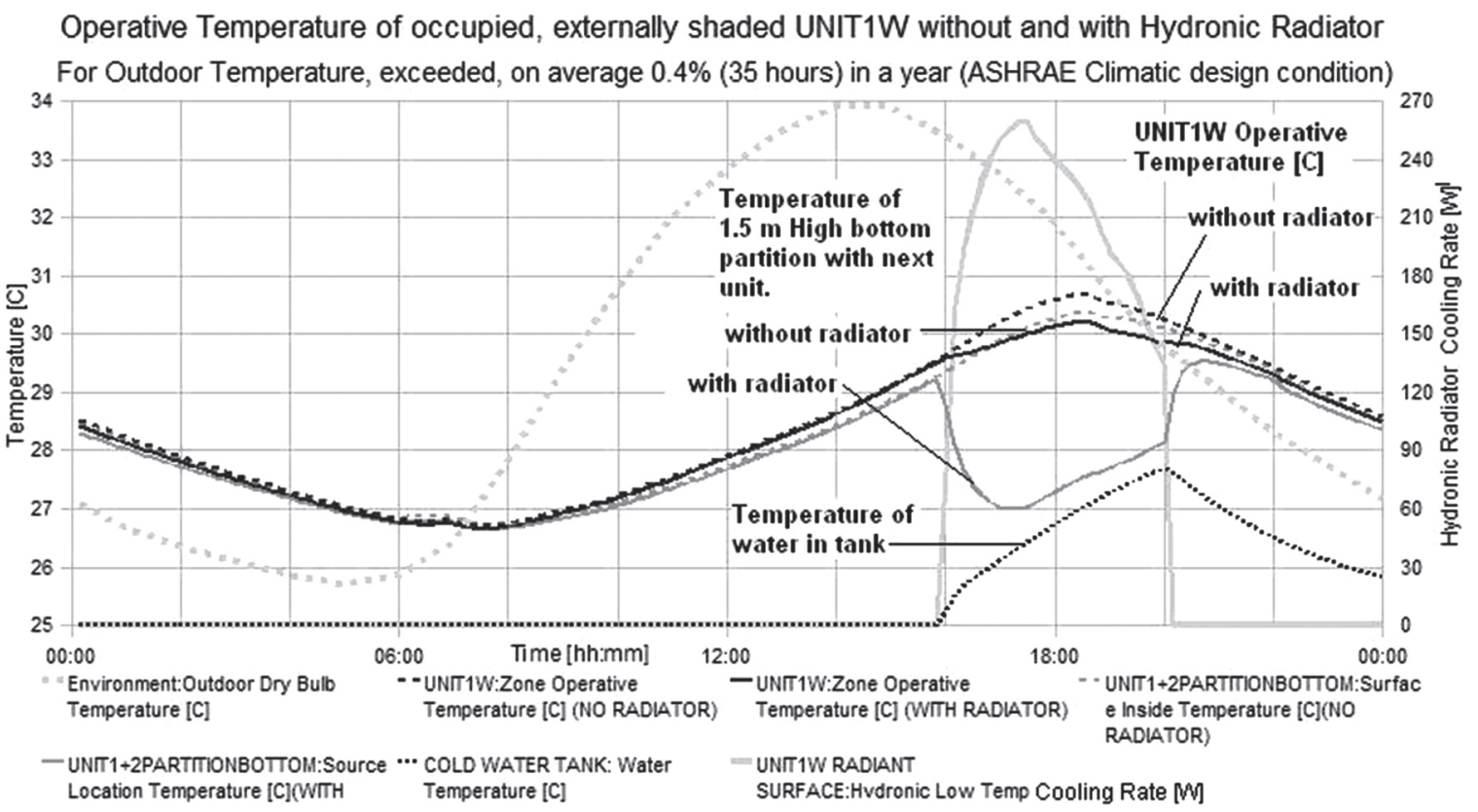


and night-time. In this study, particularly for the hours that housing occupants are normally active, two renewable sources (i.e. sunlight and geothermal heat) were utilised with the aim to achieve the desirable indoor temperature of the house's living room at $20^{\circ} \mathrm{C}$. The VGHE heat output can be increased to an average temperature of $23^{\circ} \mathrm{C}$ in Melbourne when the depth can be extended to $400 \mathrm{~m}$ from the ground. Another approach to increasing the HR temperature is to use water heated by the sun. Nonetheless, for the night-time use, the heated water needs to be stored effectively by a well-insulated tank. In the winter, solar radiation is weak or scarce; thus, moderately sized evacuated tube solar collectors or large flat plate panels need to be placed on the roof designed to receive optimal sunlight throughout the year. Some portion of building envelope (i.e. roof or wall) area can be retained for installation of a solar photovoltaic panel(s) which can generate electricity that can cover the operation of equipment pumps and fans, as well as other domestic electrical appliances.

Thermal comfort achieved by the HR space cooling system in a hot tropical climate: Water exposed to the night sky in Kuching, Malaysia, can be cooled to $25^{\circ} \mathrm{C}$ or less when measured at sunrise. The simulation results indicate that exploiting the $25^{\circ} \mathrm{C}$ night-cooled water circulating through the wall-HRs of a single-storey row house located in Kuching, when exceeding the local average outdoor temperature at $0.4 \%$ of the year, the indoor temperature can be reduced to $30.5^{\circ} \mathrm{C}$. This reduced temperature is close to the level that can be achieved through the operation of ceiling or stand fans-i.e. locally acceptable indoor temperature where air movement of $1 \mathrm{~m} / \mathrm{s}$ from a fan can create a cooling sensation of up to $4^{\circ} \mathrm{C}$. Nonetheless, despite the capacity for turning the indoor temperature into the thermally acceptable or comfortable level, the problem with the HR space cooling approach seems to be condensation. He et al. (2017) conducted a series of experiments with a room whose indoor temperature was set at $26^{\circ} \mathrm{C}, 28^{\circ} \mathrm{C}$ and $30^{\circ} \mathrm{C}$, identifying that the dewpoint was $3^{\circ} \mathrm{C}$ lower than the dry bulb temperature, when the relative humidity was $70 \%$. In fact, condensation occurred on the pipe surfaces of wall-HRs installed in this study's housing facility located in Kuching during the experiments held in June and July 2017 and the relative humidity in the room was measured at $80 \%$. The condensation issue may be alleviated or eliminated by accelerating the indoor ventilation.

The test houses built in both regions are still growing. Particularly, in Melbourne, the northeast side of the living area is currently designed to further accommodate a $3 \mathrm{~m} \times 3 \mathrm{~m}$ kitchen that contains a $200 \mathrm{~mm}$ high 'underfloor air distribution' (UFAD) plenum that embraces a 'flowthrough' HR system. Heat transfers via radiation. In view of the Stefan-Boltzmann constant of $5.67 \times 10^{-8} \mathrm{watt} / \mathrm{m}^{2} / \mathrm{K}^{4}$, the amount of heat transfer from $1 \mathrm{~m}^{2}$ of a human body having $32-35^{\circ} \mathrm{C}$ to a $20-25^{\circ} \mathrm{C}$ surface can be estimated at $43-92 \mathrm{~W}$ (Freitas Jr. 1999). Thus, HRs installed in the floor or wall have the capacity for removing the 'sensible' portion of occupants' metabolic heat. Nonetheless, the radiation cannot remove the latent portion of metabolic heat (i.e. sweat) from the surface of human bodies. Cooking and bathing also generate steam. When the HR is applied for space cooling of housing in summer, air movement (or ventilation) that helps remove the sweat becomes desirable. Upward air flow is expectedly accelerated by the proposed UFAD plenum accompanied by flow-through HRs with the support of an exhaust fan placed on the ceiling (Figure 10). The cooled or heated air in the HR integrated UFAD system will be spread from the gaps created between poly pipes and wood planks. The HR integrated UFAD system will be located in the floor of the proposed $3 \mathrm{~m} \times 3 \mathrm{~m}$ kitchen extension. Air in the adjoining living area will be drawn into this $200 \mathrm{~mm}$ high plenum positioned below the floor being also equipped with $13 \mathrm{~mm}$ diameter HR tubes that are spaced at intervals of 100 $\mathrm{mm}$ by wood strips with the aim to circulate water warmed at $14-15^{\circ} \mathrm{C}$ through VGHE. An 
FIGURE 10. Proposed 'flow-through' HRs placed on the UFAD plenum surface in the future $3 \mathrm{~m}$ $\times 3 \mathrm{~m}$ kitchen space of an experiment house in Melbourne.

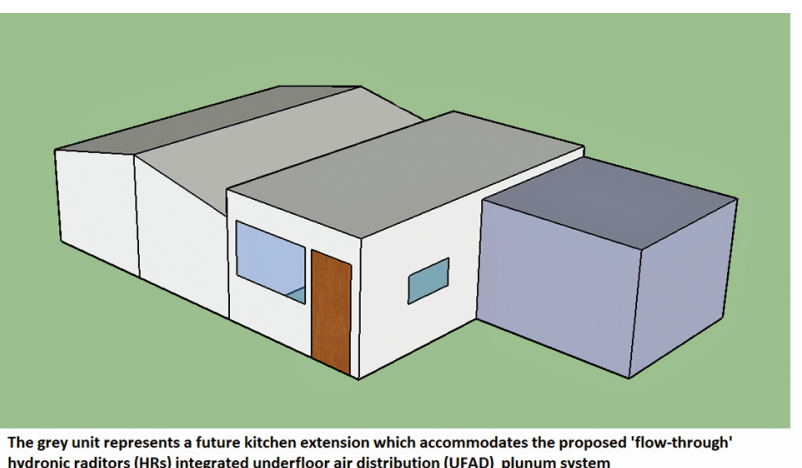

hydronic raditors (HRs) integrated underfloor air distribution (UFAD) plunum system

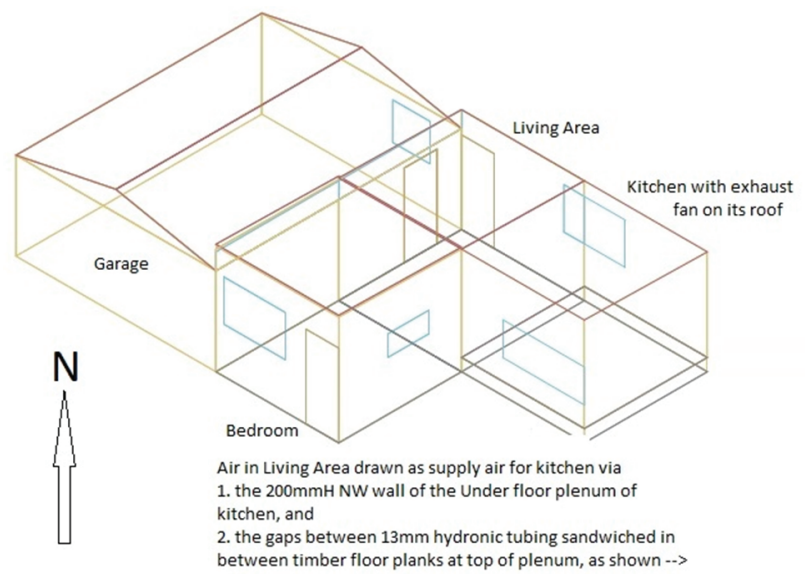

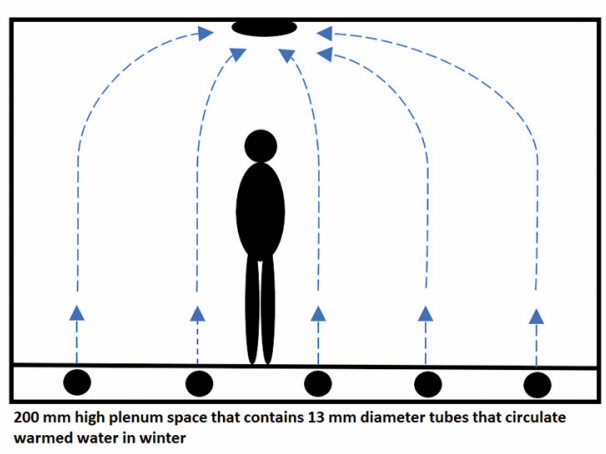

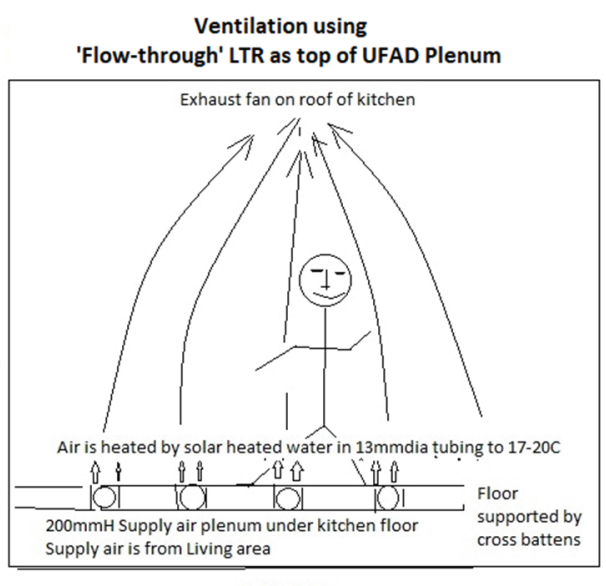

KITCHEN

exhaust fan placed at the top of the room will draw air from the adjoining living area via this UFAD plenum.

\section{CONCLUSIONS}

Energy prices are growing globally. Housing in both hot and cold regions requires proper space heating and cooling of the indoor spaces for user health and wellbeing. 'Fuel poverty' is becoming a universal conspicuous issue affecting particularly vulnerable families globally. This study proposed a new 'hydronic radiator' (HR) system that utilises free, clean renewable sources applicable to maintaining or improving indoor thermal quality of housing without relying on energy that is normally purchased from the grid. Through a series of simulation and onsite measurements, it examined space heating and cooling performance of the proposed HRs applied to housing in temperate and hot tropical climates. Housing test facilities located in Melbourne (i.e. heating dominant temperate climate), Australia, and Kuching (i.e. cooling dominant hot tropical climate), Malaysia, were selected for this simulation study. Proposed HRs circulated water heated by the $50 \mathrm{~m}$ deep ground temperature and the solar radiation or cooled by radiation to the night sky. This study drew the conclusion that the proposed HRs that only use free, clean renewable sources can contribute to securing thermally accessible and comfortable levels of housing indoor quality in both heating and cooling dominant regions. The results suggest that 
the sole use of such renewable energies for space heating and cooling can help alleviate housing fuel poverty issues. On the other hand, this study also unveiled the system's condensation problem that occurs particularly for space cooling of housing in a hot tropical climate. Housing facilities applied to this HR simulation study are still growing. Particularly, in Melbourne, the north-east side of the living area is currently designed to further accommodate a 'flow-through' HR integrated underfloor air distribution (UFAD) plenum system. The revised space heating and cooling capacities will be examined thoroughly once the system has come into operation.

\section{REFERENCES}

Benvenuti, J. (2012). The rise of fuel poverty as an Australian issue: Customers-Understanding their Needs, Wants and Expectations <https://www.cuac.org.au/consumer-a-community-resources/presentations/250-the-rise-of-fuel -poverty-as-an-australian-issue/file> retrieved on 10 November, 2018.

Chantrasrisalai, C., Ghatti, V., Fisher, D.E., and Scheatzle, D.G. (2003). Experimental Validation of the EnergyPlus Low-Temperature Radiant Simulation, ASHRAE Transactions, 109 (2), pp. 614-623.

Eskilson, P. (1987). Thermal Analysis of Heat Extraction Boreholes. Ph.D. Thesis (unpublished), Department of Mathematical Physics, University of Lund.

Freitas Jr, R.A. (1999). Nanomedicine, Volume I: Basic Capabilities, Landes Bioscience, Georgetown, TX.

He, Y., Li, N., He, M., He, D. (2017). Using Radiant Cooling Desk for Maintaining Comfort in Hot Environment, Energy and Buildings, 145: pp. 144-154.

National Renewable Energy Laboratory (2018). EnergyPlus <https://energyplus.net> retrieved on 14 November 2018.

Ooi, K. B., Noguchi, M. (2017). Verification of the Performance of a Vertical Ground Heat Exchanger Applied to a Test House in Melbourne, Australia', Energies, 10 (10): $1558<$ https://www.mdpi.com/19961073/10/10/1558> retrieved on 12 November 2018.

Yavuzturk, C., Spitler, J. D. (1999). A Short Time Step Response Factor Model for Vertical Ground Loop Heat Exchangers, ASHRAE Transactions, 105 (2): 475-485.

Zeiler, W., Boxem, G. (2008). Active House, an Alternative Sustainable Building Envelope Concept, Proceedings of the World Sustainable Building Conference (SB08), 21-25 September 2008. 
